\author{
Journal of Analytic Divinity \\ International Refereed Journal \\ E-ISSN: 2602-3792 \\ Aralik/December, 2020/4 (2): ss-pp 54/70
}

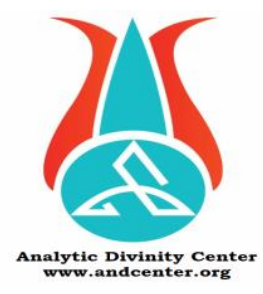

\title{
Yavuz Sultan Selim Dönemi Hilafet Telakkisi
}

The Conception of Caliphate in Yavuz Sultan Selim Era

\section{Fatih Yilmaz}

Ankara Yıldırım Beyazıt Üniversitesi, İslami İlimler Fakültesi, İslam Tarihi ve Sanatları Anabilim Dalı

Ankara Yıldırım Beyazıt University, Faculty of Islamic Sciences, Islamic History and Arts Department

Ankara, Turkey, fatihim-ylmz@yandex.com

https:// ordic.org/0000-0001-5875-1390

Makale Bilgisi | Article Information

Makale Türü / Article Type: Araştırma Makalesi / Research Article

Geliş Tarihi / Date Received: 29 Temmuz/July 2020

Kabul Tarihi / Date Accepted: 30 Kasım/November 2020

Yayın Tarihi / Date Published: 15 Aralık/December 2020

Yayın Sezonu / Pub Date Season: Kış-Aralık/ Winter-December

DOI: http:/ / doi.org/10.46595/jad.775441

Cite as / Atıf: Yılmaz, Fatih. "Yavuz Sultan Selim Dönemi Hilafet Telakkisi", Journal of Analytic Divinity 4/2 (December2020), 54-70

İntihal: Bu makale, iThenticate yazılımınca taranmıştır. İntihal tespit edilmemiştir. Plagiarism: This article has been scanned by iThenticate. No plagiarism detected.

Web: http://dergipark.gov.tr/jad | e-mail to: editorjand@gmail.com

Copyright $($ C Published by Özcan Güngör, Ankara Yıldırım Beyazıt Üniversitesi, İslami İlimler Fakültesi / Ankara Yıldırım Beyazıt University, Faculty of Islamic Studies, Ankara-Turkey. Bütün hakları saklıdır. / All right reserved. 


\section{Öz}

Hilâfet, Hz. Muhammed'in vefatından sonra İslam devletine başkanlık eden siyasî ve askerî yetkilerinin yanı sıra peygamberlik dışındaki dinî konularda Müslümanlara önderlik eden kimselerin bulunduğu makamdır. Tarihi süreçte birçok olayın doğrudan ya da dolaylı sebepleri arasında yer alan hilâfet, İslam Tarihi boyunca olduğu gibi günümüzde de üzerinde hâlâ konuşulan bir konudur. Hilâfetin Osmanlıya geçişine dair birçok kaynakta yer alan rivayetlerin farklılık arz etmesi, buradan hareketle yapılan yorumların da tarihi gerçeklik ile uyuşmaması, bizi bu konuyu ele almaya yönlendirmiştir. Hilâfetin Memlüklerden, Osmanlıya geçişiyle özdeşleşen Mısır seferi öncesi ve sonrasında padişahın bu kuruma karşı tutumunu, döneme ait kaynaklarda konunun nasıl ele alındığını irdelemeye çalıştık. Çalışmamız bağlamında şu tespitlere ulaştık: Hilâfet kurumu genel kanaatin aksine tarih boyunca önemini koruyamamış, hâlifeler yetki ve otoritelerini zamanla kaybetmişlerdir. Kuruma tekrar eski işlevselliği kazandırılmaya çalışılmışsa da mümkün olmamıştır. Yavuz Selim'in seleflerinin aksine doğuya yönelmesi hilâfeti almanın ötesinde farklı sebeplere dayandığı, söz konusu dönemde Memlükler devletindeki halifenin etkisizliği, Mısır seferi sonrasında dahi dönem kaynaklarında hâlife tabirinin kullanılmadığı, bunun birkaç müellifçe kasıtlı olarak kullandığı görülmüştür.

Anahtar Kelimeler: Hilâfet, Memlûk, Mısır, Osmanlı, Yavuz Selim,

\section{Abstract}

Caliphate is a position in which elected people leading muslims in a religious way beside their politic and military authorities that preside State of Islam after the prophet Mohammed, have. As one of the reasons of so many events' in the historical period directly or indirectly, caliphate, no doubt, has become the most debated topic even in current time. Differences between sources towards passing of caliphate on Ottomans and discrepancies between reality and comments relying on these sources, urged us to study about it. We tried to study the attitudes of Sultans's towards caliphate before and after the expedition of Egypt which became symbolic event of caliphate's passing on Ottomans, focusing on particularly first-hand sources and documents. We eventually reached some points during our study: In contrast to general idea, caliphate couldn't protect its importance throughout history, caliphs has lost their authorities in time. Despite the endeavors of revival, it never become as strong as it was once. It was reached that the reason of expedition into east by Sultan Selim I, was more unique than receiving caliphate and different from the ones before him, that Selim I hadn't so reverence for caliph, that even after the expedition, he caliphate title wasn't in use in the that time sources and that the title was used by a few writers deliberately.

Keywords: Caliphate, Mamluk, Egypt, Ottoman, Selim I. 


\section{Giriş}

Dokuzuncu Osmanlı padişahı Yavuz Sultan Selim (1512-1520), babası II. Bayezid'in (1481-1512) ardından devletin başına geçmiştir. ${ }^{1}$ Sekiz yıl gibi kısa bir sürede devlet içindeki karışıklıklara karşı tedbir alıp İran ve Mısır seferleriyle hâkimiyet alanını genişletmiştir. ${ }^{2}$ Söz konusu dönem, içinde barındırdığı birçok tarihi olayla günümüz düşünce yapısına etki etmiştir. Osmanlı devleti ve onun özelinde Yavuz Sultan Selim'e yönelik bakış açısının şekillenmesinde hilâfet meselesinin önemli olduğunu düşünmekteyiz. Sultan Selim'in nihai hedefinin mevcut hâlifeden hilâfeti ve kutsal emanetleri devralmak olduğu şeklindeki tarih anlatımını pek çok yerde görmek mümkündür. ${ }^{3} \mathrm{Bu}$ algının oluşmasında tarihî vesikaların taraflı olarak kaleme alınması, devlet erkânına yaranma ve dönemin siyasî faaliyetlerinin meşru gösterilmesi gibi kaygıların bulunması dikkat çekmektedir. Devlet kademesinde üst düzey görevlerde bulunmuş ve eserleriyle günümüze 1şık tutan önemli şahsiyetlerin devlet politikası gereği delil üretme çabası içinde olması veyahut kasıtlı övgüde bulunmaları meseleye daha dikkatli yaklaşmayı gerektirmektedir. ${ }^{4}$ Tarihî olayların tek bir sebebe indirgenerek okunması başka bir deyişle siyasî, sosyal ve ekonomik sebeplerinin göz ardı edilmesi söz konusu olayın doğru anlaşılamamasına ve yanlış algılar üzerine hüküm inşa edilmesine sebep olabilmektedir.

Söz konusu dönemin sahip olduğu nitelikler ve olaylar arasındaki sebep-sonuç ilişkisi Yavuz'un faaliyetlerinin sebebini ve hilâfet kurumuna yüklenen anlamı farklı şekilde ortaya koymaktadır. ${ }^{5}$ Siyasî ve ekonomik sebeplerin olaylara nasıl etki ettiği, beka problemi karşısında yürütülen siyasetin meşru bir zemine oturtulma gayesinin nasıl yorumlandığı, Osmanlı hilâfetinin mevcut rivayetlerdeki şekliyle vücut bulup bulmadı̆̆ı, döneme ait birincil kaynak niteliğindeki eserlerde hilâfet vurgusunun sebebi gibi etkenler çalışmamıza yön vermiştir. ${ }^{6}$ Çalışmamızda siyasî etkenlerden söz ederken sosyal ve ekonomik sebepleri çalışmanın hacmini de göz önünde bulundurarak kısaca değindik.

\section{Abbâsîler ve Yavuz Sultan Selim Döneminde Hilâfet Kurumunun Önemi}

Sözlükte "birinin arkasından gelmek, yerine geçmek, birinin yerine geçerek onun adına iş yapmak" anlamlarına gelen hâlife kelimesi, daha çok devlet başkanı, en yüksek yönetici olarak tanımlanmaktadır. ${ }^{7} \mathrm{~Hz}$. Muhammed'in ardından devlet başkanı sıfatıyla yönetimi elinde bulunduran, dünya işlerini düzenleyen ve onun adına dini koruyan

\footnotetext{
1 Matrakçı Nasuh, Rüstem Paşa Tarihi Olarak Bilinen Târih-i Âl-i Osmân, ed. Erhan Afyoncu, çev. Göker İnan, (İstanbul: Türkiye Yazma Eserler Kurumu Başkanlığı Yayınları, 2019), 307-310.

2 Hadîdî, Tevârih-i Âli Osman, çev. Necdet Öztürk (İstanbul: Marmara Üniversitesi Yayınları, 1991), 405.

3 Namık Sinan Turan, Hilafet: Erken İslam Tarihinden Osmanlı'nın Son Yüzyılına (İstanbul: İstanbul Bilgi Üniversitesi Yayınları, 2017), 3.

4 Vural Genç, Acem'den Rum'a Bir Bürokrat ve Tarihçi İdris-i Bidlîŝ̂, (Ankara: Türk Tarih Kurumu Yayınları, 2019), 416.

5 Ş. Tufan Buzpınar, "Osmanlı Hilafeti Meselesi: Bir Literatür Değerlendirmesi”, Türkiye Araştırmaları Literatür Dergisi 2/1 (2004), 113-131.

${ }^{6}$ Faruk Sümer, “Yavuz Selim Hilafeti Devraldı mı?”, Belleten Dergisi 56/217 (Aralık 1992), 21. Turan, Hilafet, 5.

7 Fikret Karaman, "Hâlife", Dini Kavramlar Sözlüğü, ed. İsmail Karagöz (Ankara: Diyanet İşleri Başkanlığı Yayınları, 2010), 226.
} 
kimselere verilen bir sıfat olmuştur. Tarihi süreçte bu makamı ifade eden başka kavramlar da kullanılmıştır. Hilâfetin, Yavuz dönemindeki önemini kavrayabilmek adına kurumun pratik anlamda dönüşüm yaşadığı Abbâsîler dönemiyle başlayıp Memlükler yönetiminde kazandığı niteliği zikretmeyi uygun gördük.

Hilâfet kurumu, tüm İslam coğrafyasında kabul gören, hâkimiyet unsurlarını bünyesinde barındıran ve edindiği birleştirici rolüyle Hulefâ-i Râşidûn denilen Dört Halife döneminden Abbâsîlerin son zamanlarına kadar gelmiştir. Abbâsîlerin siyasî, sosyal ve ekonomik alanda ulaştıkları refah, hilâfet kurumunun güç kazanmasını sağlarken bu alanlarda yaşanan krizler hilâfet anlayışında değişimlere neden olmuştur. Merkezden yönetici olarak görevlendirdiği kimseler aracılığıyla sahip olduğu toprakları yöneten hâlifeler, devletin güç kaybetmesiyle otoritelerinden ve yetkilerinden bu kimseler lehine feragat etmeye başlamışlardır. ${ }^{8}$ Hâlifelerin bu dönemde tek yapabildikleri zikredilen yöneticilerin başına buyruk yönetimlerini tanımak ve gelen hediyelere karşı hil'at ve menşur göndermekten ibaret olmuştur. ${ }^{9}$ Abbâsîlerin son dönemlerinde gerçek anlamda hilafet makamını yürüten Abbasi halifeleri yerine dış kontrole açı, vasıfsız ve yeteneksiz halifeler iş başına gelmeye başlamıştır. İlerleyen süreçte Karmatîler ve Fatımîler gibi Şii hanedanlıklarının bağımsızlıklarını ilan etmeleriyle Abbâsîlerin merkezi hilâfet iddiası sekteye uğramış ve Abbâsî hilâfetinin yanı sıra Büveyhî-Fatımî hâlifeliği ve Endülüs Emevî hilâfeti ortaya çıkmıştır. ${ }^{10}$ Moğolların 1258 yılında eski ihtişamından çok uzakta olan Abbâsî hilâfetine son vermesiyle hilâfet müessesesi hem teoride hem de uygulamada etkin güç olma özelliğini yitirmiş, siyasî ve idarî hâkimiyet sultanlara geçmiştir.11

Abbâsî hilâfetinin yıkılmasının ardından Memlükler Kahire'de Abbâsî hilâfetini yeniden ihdas etmiştir. Ancak Kahire'deki hâlifeler, Abbâsî hâlifesinin elinde kalan son yetkilerden ikta tahsisi,12 memurları tayin ve azletme gibi haklardan da mahrum kalmışlardır. Bunun yerine belirli aralıklarla huzura çıkıp sultanı selamlama ve tebrikte bulunmak, savaşa gidecek orduyu dinî lider vasfiyla motive etmek, tertip edilen bazı meclislere iştirak etmek, hükümdarlığına dini meşruiyet kazandırmak isteyen hükümdarlara menşur göndermek gibi hâlifeliğin asıl niteliklerden çok uzakta görevlerle meşgul olmuşlardır. ${ }^{13}$ Sultanlar, hilâfet makamına Abbâsî soyundan diledikleri kişiyi tayin etmişler ve istedikleri unvanı kullanmalarını sağlamışlardır. Tüm bunlar hiçbir otoritesi ve siyasi etkinliği kalmayan hâlifelerin, sultanın nüfuzu altında bulunan maaşlı bir devlet memuru görünümü kazandığı fikrini vermektedir. ${ }^{14}$ Öte yandan mevcut hâlifelerin İslam

\footnotetext{
8 Turan, Hilafet, 83.

${ }^{9}$ Mustafa Alkan, Osmanlılarda Hilafet (İzmir: Çağlayan Yayınları, 1997), 35.

10 Alkan, Osmanlilarda Hilafet, 21.

11 Nesimi Yazıc1, İlk Türk-İslam Devletleri Tarihi (Ankara: Türkiye Diyanet Vakfı Yayınları, 2016), 214; Alkan, Osmanlılarda Hilafet, 78.

12 İkta: Sözlükte "kesmek, ayırmak" anlamındaki kat' kökünden türetilen İkta kelimesi, terim olarak, devlet başkanı veya onun adına yetki kullanan merci tarafından özellikle arazi gibi taşınmaz mallarla maden ocağı ve benzeri tabii kaynakların mülkiyet (temlik), işletme yahut faydalanma hak veya imtiyazlarının ya da bir bölgenin vergi gelirlerinin uygun gördüğü kimselere tahsisini ifade eder. Mehmet Zeki Pakalın, "İkta", Osmanlı Tarih Deyimleri ve Terimleri Sözlü̆̆̈̈̈, (İstanbul: Milli Eğitim Basımevi, 1971), 2/1-2.

${ }^{13}$ Abdullah Mesut Ağır, "Memlûk Sultanlarının Gölgesi Altında Hilâfet Kurumu”, Gaziantep Üniversitesi Sosyal Bilimler Dergisi 10/2 (2011), 642.

${ }^{14}$ A ̆̆ır, "Memlûk Sultanlarının Gölgesi Altında Hilâfet Kurumu",643; Cemil Hakyemez, "İbn Haldun ve İmametSiyaset Algısında Farklılaşma arayışları", Uluslararası İbn Haldun Sempozyumu, ed. Mesut Okumuş (Çorum: Çorum Belediyesi Kültür Yayınları, 2013), 70.
}

Journal of Analytic Divinity, https://dergipark.org.tr/tr/pub/jad Volume $4 / 2$ 
dünyasındaki etki alanları Abbâsî hâlifelerine nazaran daha sınırlı olmuştur. ${ }^{15}$ Memlükler, her ne kadar kutsal şehirleri ve hac yollarını himaye etmeleri ve Abbâsî hâlifelerini yanlarında bulundurmalarıyla İslam âleminin en nüfuzlu devleti olduklarını iddia etseler de etki alanları sınırlı kalmıştır.

Memlük-Osmanlı ilişkilerine baktığımızda Osmanlılar, Mısırdaki hâlifeyi tanımışlar ve bu tanımanın gerektirdiği sorumlulukları yerine getirmişlerdir. Hâlifeye saygı duymuşlar ve yönetimlerine dinî meşruiyet kazandırmak amacıyla hâlifeden menşur, unvan talebinde de bulunmuşlardır. ${ }^{16}$ Etki alanı sınırlı olan bu hâlifeyi Osmanlıların niçin tanıdığ1 sorusu akla gelebilir. Bize göre Osmanlılar tıpkı Selçuklular gibi Sünnî İslam birliğinin Şiî blok karşısında tamamen etkisiz kalmasını önlemek ve kutsal toprakları elinde bulunduran otoriteyle iyi ilişkiler kurmak istemektedir. ${ }^{17}$

Osmanlıların en başından beri edindikleri misyonla gazâ faaliyetlerine yönelmeleri İslam dünyasında sayg1 ve üstünlük elde etmelerine vesile olmuştur. ${ }^{18}$ Üstüne Doğu Roma (Bizans)İmparatorluğuna son vererek pek çok İslam devletinin gerçekleştirmek isteyip de muvaffak olamadığı, İstanbul'u fethetmeleriyle İslam dünyasında siyasî nüfuz ve kudret sahibi olmuşlardır. ${ }^{19}$ İstanbul'un fethiyle birlikte cihanşümul bir devlet düşüncesine geçiş, yürütülecek tüm politikalarda değişikliğe sebep olmuştur. Söz konusu değişiklikle birlikte hâlifeyle olan ilişkilerde etkilenmiş ve başlangıçta mevcut halifenin üstünlüğünün kabul edildiği ilişkiler yerini Osmanlı yöneticilerinin önceliğine bırakmıştır. ${ }^{20}$ Fatih Sultan Mehmet, İstanbul'u fethettikten sonra Memlüklere gönderdiği fetihnâmede kendisini Sultanu'l-Guzât ilan ederek, gazâ ve cihat yolunda mücahitlere önderliğin kendisinde hac farizasının gerçekleştirilmesi görevinin ise Memlüklerde olduğunu ifade etmiştir. ${ }^{21}$ Öte yandan padişahların resmi yazışmalarda Mısır'daki hâlifeye "hâlife" unvanıyla hitap etmemesi bu fikrimizi destekler niteliktedir. ${ }^{22}$

Otoritesi ve siyasî yetkisi bulunmayan sembolik halifenin ve hilafet kurumunun I. Selim tarafından istenilmesi ne kadar mümkün sorusu akla gelmektedir. Bu sorumuza cevap ararken Osmanlı devletinin o dönemdeki siyasî gücü ve uluslararası alandaki itibarını göz ardı etmemek gerekir.

Fatih'in kendisini Roma tahtının yegâne ve meşru varisi görmesi, Doğu kaynaklarında İslam'ın en güçlü hükümdarı olarak anılırken Batı kaynaklarında İskender

\footnotetext{
15 Anadolu Selçukluları sonrası Anadolu Beylikleriyle, Doğu Anadolu'da kurulan Karakoyunlu, Akkoyunlu Devletleri ve Orta Asya'da Timur devletiyle devamındaki hanedanlıkların Mısır Abbasî halifelerinden habersiz olduğu zikredilmektedir. Öte yandan diğer İslam coğrafyalarının Fatımi halifeliğinin tesiri altında bulunması zikredilen etki alanını daha da azaltmıştır. Alkan, Osmanlılarda Hilafet, 73.

16 Alkan, Osmanlilarda Hilafet, 78.

${ }_{17}$ Arif Erdoğan, Yavuz Sultan Selim'in Faaliyetlerinde Din ve Siyaset Faktörü (Ankara: Ankara Üniversitesi, Sosyal Bilimler Enstitüsü, Yüksek Lisans Tezi, 1998), 35.

18 Turan, Hilafet, 188.

${ }^{19}$ Matrakçı Nasuh, Târih-i Âl-i Osmân, 258.

20 Turan, Hilafet, 231.

${ }^{21}$ Feridun Ahmet Bey, Münşeâtü's-Selâtîn (Ankara: TBMM Kütüphanesi, 71-5305), 1858), 236.

22 Alkan, Osmanlilarda Hilafet, 79-81.
} 
tahtına oynayan, Roma'nın yeni imparatoru olarak tasvir edilmesi ${ }^{23}$, bize Osmanlıların zihinsel olarak devlet idealinden büyük bir cihan devleti idealine geçişini ifade etmektedir. İslam dininin bayraktarlığını hilâfetin devralınmasından önce de gazâ ve cihat faaliyetlerindeki öncülükle elinde bulunduran Osmanlıların, söz konusu önderlikte makama ihtiyaç duymadığı görülmektedir.

\section{Yavuz Sultan Selim'in Siyasî Mücadeleleri}

Yavuz Sultan Selim'in seleflerinin aksine yüzünü öncelikli olarak batıya değil de doğuya çevirmesiyle ilgili anlatımlarda sıklıkla hilâfet kurumu ve öneminin altı çizilmektedir. Sultan I. Selim'in öncelikli hedefinin hilâfet kurumu olduğu ve İslam âleminde otoritesini güçlendirme isteği ifade edilmektedir. ${ }^{24}$ Bize göre Sultan I. Selim'in faaliyetlerinin yalnızca bu bağlamda ele alınmaması, onun faaliyetlerindeki dini hassasiyetin yanı sıra siyasî, sosyal, ekonomik hedeflerinde gözetilmesi gerekmektedir. Bu bahis başlı başına bir makale konusunu teşkil edecek genişliği sahiptir. Ancak hilâfet konusunda yapılan pek çok yorumun doğu seferi özelinde vücut bulması bizi kısada olsa meseleyi ele almaya yöneltmiştir. Doğru bir bakış açısı için öncelikli olarak Yavuz Sultan Selim'in niçin doğuya sefer düzenlediği, yakın ve uzak anlamda hedefinin ne olduğu, dönem kroniklerinde yalnızca dinî sebeplerin ön plana çıkarılmasının kasıtlı mı yahut başka sebeplere binaen mi dile getirildiği sorularına cevap aramamızın daha isabetli olacağını düşünmekteyiz.

XVI. yüzyıl sosyo-ekonomik anlamda uluslararası siyasette değişimin yaşandığı bir dönem olarak Osmanlıların da politik ve ekonomik anlamda yeni arayışlar içinde olduğu bir dönem olmuştur. Osmanlı siyasetine yön veren etmenlerin başında Akdeniz ve Hint Okyanusundaki faaliyetleriyle Osmanlı menfaatlerini ciddi ölçüde tehdit eden Portekiz'le mücadeleler ön plana çıkmaktadır. ${ }^{25}$ Portekiz'in bu bölgede kurmayı hedeflediği bir deniz imparatorluğu Osmanlı'nın güney ve doğu bölgesi için aktif politikalar üretmesini zorunlu kılmıştır. ${ }^{26}$ Portekiz nüfuzunu kırmak isteyen Osmanlılar, ekonomik ve stratejik öneme sahip Mısır'ı alarak Akdeniz' de güç olmak, Orta Asya ile kara bağlantısı kurarak buradaki hâkimiyetlerini pekiştirme amacı gütmüşlerdir. ${ }^{27}$ Portekiz' in söz konusu ticaret ağını tehdit etmeye başlaması bölgedeki Safevîler, Memlükler ve Venediklilerin de bu mücadeleye katılmalarıyla konjonktüre göre belirlenen ittifak ve savaşlara sebep olmuştur. Bu taraf oluşlarda din unsuru değil, daha çok siyasî gayeler etkili olmuştur. ${ }^{28}$ Söz konusu siyasi mücadeleye Müslüman üç devlet arasındaki hâkimiyet mücadeleleri eklenince dönem olayları arasında girift bir yapı meydana gelmektedir. ${ }^{29}$

\footnotetext{
23 Turan, Hilafet, 190.

24 İdrîs-i Bidlîsî, Selim Şah-Nâme, çev. Hicabi Kırlangıç, (Ankara: Kültür Bakanlı̆̆ı Yayınları, 2001), $239-242$.

${ }^{25}$ Halil İnalcık - Donald Quataert, Osmanlı Imparatorluğu'nun Ekonomik ve Sosyal Tarihi, çev. Halil Berktay (İstanbul: Eren Yayıncılık, 2000), 378-380.

${ }^{26}$ Ayşe Pul, "Yavuz Sultan Selim'in Güney Siyasetinin Doğu Akdeniz Ticaretine Etkisi Hakkında Bazı Düşünceler", Selçuk Üniversitesi Türkiyat Araştırmaları Dergisi 35 (Haziran 2016), 264.

27İsmail Hakkı Uzunçarş1lı, Osmanlı Tarihi (Ankara: Türk Tarih Kurumu Yayınları, 1988), 6/293; Turan, Hilafet, 200.

28İnalcık - Quataert, Osmanlı İmparatorluğu'nun Ekonomik ve Sosyal Tarihi, 378; Uzunçarş1lı, Osmanlı Tarihi, 6/249. ${ }^{29}$ Celâlzâde Mustafa Çelebi, Selim-Name, çev. Ahmet Uğur- Mustafa Çuhadar (Ankara: Kültür Bakanlığ1 Yayınları, 1990), 410-415.
}

Journal of Analytic Divinity, https://dergipark.org.tr/tr/pub/jad Volume $4 / 2$ 
II. Bayezid döneminde devletin iç işleyişinde meydana gelen aksaklıklar ${ }^{30}$ hem otorite hem de sosyo-ekonomik anlamda bozulmalara neden olmuştur. ${ }^{31}$ Şiî düşünce etrafında şekillenen Safevî devletini kurarak (907/1502)32 Azerbaycan'dan Irak'a, İran'dan Ceyhun nehrine kadar olan topraklarda hâkimiyet kuran Şah İsmâil, Anadolu halkının Erdebil tekkesine ${ }^{33}$ olan muhabbet ${ }^{34}$ ve bağlılı̆̆ın1 ${ }^{35}$ kullanarak Anadolu'da faaliyet göstermeye başlamıştır. ${ }^{36}$

Birçok araştırmacı Yavuz'un doğu seferini Şah üzerine gösterip hilâfete yönelik gerçekleştirdiği bir siyasi manevra olarak yorumlasada ${ }^{37}$ bize göre durum farklı aksetmiş bulunmaktadır. Sultan I. Selim, Anadolu halkından azımsanmayacak bir kesimin Safevî devletinin propagandasına muhatap olmasını bir tehdit olarak nitelendirmiştir. ${ }^{38}$ Babasından farklı olarak Anadolu'daki ayaklanmaları bir iç mesele olarak görmemiş aksine siyasi, askerî ve ticarî anlamda bir beka problemi olarak değerlendirmiş, problemin İran'daki kaynağını bitirmeye karar vermiştir. ${ }^{39}$ Diğer taraftan Safevîler, Osmanlıyla sünnî orta Asya müslümanları arasında bir blok oluşturmuş, Batı'yla mücadele halindeki Osmanlıya doğudan gelebilecek yardımların önünü kesmiştir. ${ }^{40}$

Netice itibariyle Osmanlıyı ideolojik anlamda yapılanmaya sevk ederek belki de o güne kadar kesin çizgilerle vurgulamak zorunda kalmadığı sünnîliğin hamiliğini yüklenmesine vesile olmuştur. ${ }^{41}$ Şah İsmâil'le olan mücadele anlatılırken Yavuz Selim'in

\footnotetext{
${ }^{30}$ Yavuz Selim, Babası II. Bayezid'in hem mizacı hem de yaşı itibariyle otoritesini vezirleri lehine kaybetmeye başlamasını görmüş ve bu konuda yapılması gerekenleri dile getirmiştir. Ancak gerekli önlemler alınmayarak vezirlerin devlet işlerini kendi arzuları doğrultusunda yürütmesine göz yumulmuştur. Kötü gidişattan memnun olmayan halk ise iktidar aleyhine yeni arayışlar içine girmeye başlamıştır.

31Uzunçarşılı, Osmanlı Tarihi, 6: 228; Ahmet Uğur, İbn-i Kemâl (İzmir: Kültür ve Turizm Bakanlığı Yayınları), 6. 32Uzunçarş1lı, Osmanlı Tarihi, 6: 244.

${ }^{33}$ Erdebil Tekkesi, Safüyiddin-i Erdebîlî (ö. 735/1334) tarafından Erdebil şehrinde kurulan Kurucusunun adına nispetle Safeviyye, kurulduğu Erdebil şehrine nispetle Erdebîliyye olarak anılan bir tarikattır. Başlangıçta Sünni bir tarikat olan Erdebil tekkesi Şah İsmail'in büyük dedelerinden Şeyh Cüneyt itibariyle Şii düşüncenin etkisine girmiştir. Bu süreç itibariyle tarikatın takipçileri silahlandırılmaya ve siyasi anlamda mücadeleye girişilmiştir. Osmanlı devleti sınırlarında yer alan Anadolu'da iyi ilişkiler kurarak pek çok kesimden taraftar edinmişlerdir. Reşat Öngören, "Safiyüddîn-i Erdebîlî" Türkiye Diyanet Vakfi İslam Ansiklopedisi (Erişim 23 Ocak 2020).

34 Öyle ki halktan azımsanmayacak bir kesimin ve devlet ricalinin bir kısmının Sultandan çok Şah'a saygı duyduğu ifade edilmektedir. Şükrî-i Bitlisî, Selîm-nâme, çev. Mustafa Argunşah (Kayseri: Erciyes Üniversitesi Yayınları, 1997), 83.

35Cenksu Üçer, Tokat Yöresinde Geleneksel Alevîlik (Ankara: Ankara Okulu, 2015), 163; Uzunçarş1lı, Osmanlı Tarihi, $6 / 223$.

36 Ülkenin içinde bulunduğu siyasî ve ekonomik kötü durumu kullanan Şah taraftarları Şah'ın ülkesinde refah bir hayat olduğunu, halka adaletli davranılıp dirliğin hak eden kimselere verildiğini söyleyerek halkı göç etmeye yöneltmişlerdir. Dirlik: hizmet karşılığında devlet görevlilerine ve savaşlarda yararlılık gösteren askerlere tahsis edilen gelir kaynaklarına denilirdi.

37Feridun Emecen, "Selim I" Türkiye Diyanet Vakfi İslam Ansiklopedisi (Erişim 12 Ocak 2020).

${ }^{38}$ Ahmet Şimşirgil, KAYI III Osmanlı Tarihi- Haremeyn Hizmetinde, (İstanbul: Timaş Yayınları, 2013), 157.

${ }^{39}$ Hoca Sadettin Efendi, Tacü't-Tevarih, çev. İsmail Parmaksızoğlu, (İstanbul: Devlet Kitapları Müdürlügüu-Millî Eğitim Bakanlığı Yayınları, 1979), 84; Cemil Hakyemez, Osmanlı-İran İlişkileri ve Sünni-Şii İttifakı, (İstanbul: Kitap Yayınevi, 2014), 23; Şimşirgil, Kayı, 155.

40Hakyemez, Osmanl-İran İlişkileri ve Sünni-Şii İttifakl, 23.

${ }^{41}$ Adnan Ulutaş, Osmanlı İmparatorluğu'nda Hilafet ve Saltanat Müesseselerinin Hukuki Mahiyeti (İstanbul: İstanbul Üniversitesi, Sosyal Bilimler Enstitüsü, Yüksek Lisans Tezi, 2007), 163.
} 
dönem eserlerinde Ehl-i Sünnet müslümanlarının koruyucusu olarak zikredilmesinin bu gayeye yönelik olduğunu düşünmekteyiz.42 Şah’ın İran ve Asya'daki topraklarında hâkimiyet kurma arzusu ${ }^{43}$ olan Yavuz'un faaliyetleri dönem eserlerinde Şiiliğe karşı yapılan mücadele olarak ön plana çıkarılmakta ${ }^{44}$ yapılanların İslam dini için yapıldığı mesajı sıklıkla dile getirilmektedir. ${ }^{45}$ Burada söz konusu mücadeleye dinî bir karakter kazandırarak meşruiyet sağlama ve sefere çıkma noktasında isteksiz davranan askeri cepheye götürebilme gayesi akla gelmektedir. ${ }^{46}$ Öte yandan Sultan I. Selim'in Misır seferi sonrasında dahi Hindistan ve Çin haritaları hazırlatması öncelikli hedefinin Asya olduğunu ve burada hâkimiyet kurarak Doğudan-Batıya ulaşacak zenginlikleri kontrol etmek için mücadele ettiğini göstermektedir. İ. Hakkı Uzunçarşılı'ya göre bu gerçek “Asıl maksadı Safevî devletini ortadan kaldırmak ve Orta-Asya'ya kadar gidip oralardaki Sünnileri nüfuzu altına almaktı" şeklinde ifade edilmiştir. ${ }^{47}$ Oradaki Sünniler üzerinde hâkimiyet kurmak demek Asya açıklarında kolonileşen Portekiz'e darbe vurmak demektir.

Safevîlerle yapılan Çaldıran savaşı sonrasında ikinci bir İran seferi için hazırlık yapan Yavuz Selim Memlükleri cephe gerisinde bir tehdit unsuru olarak görmekteydi. ${ }^{48}$ Söz konusu tehdidi bertaraf etmek için Memlüklere iyi dilek ve temennide bulunan Yavuz Sultan Selim, katılmayacaklarını bildiği halde seferde kendisine yardımcı olmalarını teklif etmiştir. ${ }^{49} \mathrm{Bu}$ adımla I. Selim, Memlüklerin kendilerine karşı itimatsızlığı varsa önlemek, tarafsızlıklarından emin olmak ve muhtemel saldırılarından emin olmak istemiştir. Rivayete göre bu sırada Şah İsmâil Memlüklere müracaat ederek "Yavuz tehlikesi bir kez daha Acem üzerine yürüyecek olursa ona karşı durabilecek bir güç yoktur. Acemden sonra ise hedefi Arap (toprakları) olacaktır" diyerek Osmanlılara karşı birlikte hareket etme teklifinde bulunmuştur. ${ }^{50}$ Eğer Şah üzerine bir saldırı olursa Memlüklerin destek vereceğini, Memlük üzerine bir saldırı olursa Şah ve askerlerinin yardımcı olacağını ifade eden gizli bir anlaşma yapılmıştır. Yapılan anlaşmaya uygun hareket eden Memlükler, siyasetleri gereği tarafsız kalacaklarını ve vaziyeti tetkik maksadıyla Halep yakınlarında ordu bulunduracaklarını söyleyerek asıl maksatlarını uygulamaya çalışmışlardır. ${ }^{51}$ Böylece farklı mezheplerdeki Şah-Gavri ittifakına kapı aralanmış oluyordu. Yavuz Selim ise Şubat 1516 ‘da gönderdiği bir namesinde; "Sultan benim pederimdir ondan dua isterim52; lâkin benimle Şah İsmail arasına girip tavassut etmesin; ben şahın çadırın yeryüzünden kaldırmayınca dönmeyeceğim, sulh için aramıza girmesin" "aramızda babalık, evlâtlık varsa Suriye'den Kahire'ye avdet etsin."

\footnotetext{
42Matrakçı Nasuh, Târih-i Âl-i Osmân, 320.

${ }^{43}$ Hoca Sadettin Efendi, Tacü't-Tevarih, 92; Şükrü Bitlisî, Selîm-nâme, 104. Şark ehli ile var gönlümde cenk arzum niyetim şeksiz budur" demekte Yavuz Selim.

${ }^{44 K a y h a n ~ A t i k, ~ L u ̈ t f u ̈ ~ P a s ̧ a ~ v e ~ T e v a ̂ r i h-i ~ A ̂ l i ~ O s m a n ~(A n k a r a: ~ K u ̈ l t u ̈ r ~ B a k a n l ı g ̆ ı ~ Y a y ı n l a r ı, ~ 2001), ~ 82-83 . ~}$

45Şefaettin Severcan, Kemalpaşazâde Tevarih-i Al-i Osman 10. Defter (Kayseri: Erciyes Üniversitesi, Sosyal Bilimler Enstitüsü, Doktora Tezi, 1991), 52; Uzunçarşılı, Osmanlı Tarihi, 6/249; Üçer, Alevîlik, 177.

${ }^{46}$ Orduda Şah'a gönülden bağlı olanların yanı sıra Yeniçerilerin Bektaşi tarikatına müntesip olmaları ve Hz. Ali'ye büyük sevgi duymaları Şah'a karşı savaş sırasında problem oluşturabilir düşüncesini meydana getirmiştir.

47Uzunçarşılı, Osmanlı Tarihi, 6/292-293.

${ }^{48}$ Hoca Sadettin Efendi, Tacü't- Tevarih, 225-230; Uzunçarş1lı, Osmanlı Tarihi, 6/258.

49Şükrü Bitlisî, Selîm-nâme, 243.

${ }^{50}$ Celâlzâde Mustafa Çelebi, Selim-Name, 403; Atik, Lütfü Paşa ve Tevârih-i Âli Osman, 112.

${ }^{51}$ Şükrü Bitlisî, Selîm-nâme, 247; Uzunçarşılı, Osmanlı Tarihi, 6/249; Şükrü Bitlisî, Selîm-nâme, 247; Hoca Sadettin Efendi, Tacü't- Tevarih, 186.

52Matrakçı Nasuh, Târih-i Âl-i Osmân, 320.
}

Journal of Analytic Divinity, https://dergipark.org.tr/tr/pub/jad Volume $4 / 2$ 
demiştir. ${ }^{53}$ Ancak Gavri ve ordusu Halep'ten ayrilmayarak teklifi reddetmiştir. ${ }^{54}$ Bunun üzerine Yavuz Selim, Memlükler üzerine sefer düzenleyerek Safevî-Memlük birliğini sekteye uğratmıştır.

Gazze'ye kadar Memlük topraklarını ele geçiren Yavuz Selim, zaferinin tescili için Mısır'ın mutlaka alınması gerektiğini düşünüyordu. ${ }^{55}$ Ancak Mısır üzerine gidilirken Abbâsîlerdeki gibi güç ve görkeme sahip bir hâlife ve hilâfet kurumu bulunmamaktayd1. ${ }^{56}$. Memlük birliklerinin Ridâniye' deki Mısır şehrini savunma gayretleri sonuç vermemiş ve Osmanlı ordusu karşısında yenilmişlerdir. Bu galibiyet üzerine Mısır, Osmanlı devleti egemenliğine girmiş ve Memlük sultanlığı fiilen sona ermiştir. ${ }^{57} \mathrm{Bu}$ seferin ardından iki büyük rakibini etkisiz hale getiren Yavuz Selim'in önünde ideallerini gerçekleştirmesi için engel kalmamıştı. Akdeniz'i bir Türk denizi yapmak isteyen Sultan Selim, vakit geçirmeden bu işe başlanmasını emretmiştir. Mısır'ın ve Kızıldeniz'in karşılıklı iki sahiline sahip olan Osmanlılar Hint ve Akdeniz arasındaki Kızıldeniz ticaret yoluna hâkim olmuş, Portekiz ve diğer rakipleri karşısında elini güçlendirmiştir. 58

Döneme ait kaynaklarda Yavuz Selim'in faaliyetlerinin objektif bir şekilde ele alınmadığı görülmektedir. Yavuz ve Şah İsmâil arasındaki mücadelenin yalnızca bir mezhep çatışması gibi nakledildiği, Sünnîlik ve Şiîlik arasındaki mücadelenin ön plana çıkarıldığı gözlenmektedir. ${ }^{59}$ Dönem kaynaklarının pek çoğunu okuyan kimse Yavuz Selim'in yalnızca mezhebi bir tutumla din adına mücadele ettiği izlenimine kapılabilir. Ancak tarihi olayları eleştirel bir gözle incelediğimizde Osmanlı-Safevî mücadelesinin yalnızca bir mezhep çatışması üzerine kurulmadığı sonucuna ulaşabiliriz. Her iki tarafta mezhebi propagandayı ön plana çıkarsa da asıl sebep dönemin jeopolitik özelliklerinden kaynaklanan siyasî gaye ve amaçlara dayanmaktadır. Zira Osmanlılar sırf Sünnîlik güdüsüyle hareket etmiş olsaydı Sünnî bir devlet olan Memlüklerle savaşmaması gerekirdi. Öte yandan Sünnî Memlük devletinin hiçbir kaygı gütmeden Safevî tehlikesi karşısında Osmanlıları desteklemesi gerekirdi ki bunun tersine bir tarihi gerçeklik karşımıza çıkmaktadır. ${ }^{60}$ Osmanlı Devleti'nin uluslararası konumu pekiştirmek adına iki Müslüman devletle savaşmayı göze alması da bize göre dini hassasiyetlerin ötesinde bir hedefinin olduğunu göstermektedir. Öte yandan dinin sağladı̆̆ 1 hareket sahasını liderler iyi kullanılarak kitleleri daha kolay harekete geçirmişlerdir.

\footnotetext{
${ }^{53}$ Ahmet Uğur vd., Kitâbüt- Târih-i Künhü'l- Ahbâr Gelibolulu Mustafa Âli Efendi, (Kayseri: Erciyes Üniversitesi Yayınları, 1997), 1163; Atik, Lütfü Paşa ve Tevârih-i Âli Osman, 66.

54 Burası memleketimdir gitmem diyerek teklifini reddetmiş olan Gavri 'ye Yavuz, "Sen açık düşmanmışsın, Şah Ismail ortada yok. Senin Halep'te olman benim askerime ve vilayetime hayırlı değildir. Senin düşmanliğın göz önünde dururken, ben görünmez düşmana varı seni arkamda komam(koymam)"demiştir.

55 Mısır, söz konusu dönemde jeopolitik konumu ve gelişmiş ekonomik yapısıyla gözde bir şehirdir. Matrakçı Nasuh, Târih-i Âl-i Osmân, 321.

56 Turan, Hilafet, 128.

57 Nihat Azamat, Anonim Tevarih-i Ali Osman (İstanbul: Marmara Üniversitesi Yayınları, 1992), 138.

58 Uzunçarşılı, Osmanlı Tarihi, 6/279-284.

59 İdris-î Bidlîsî, Selim Şah-Nâme,198; Matrakçı Nasuh, Târih-i Âl-i Osmân, 310-315; Uğur vd., Künhü'l- Ahbâr, 1165; Genç, Acem'den Rum'a Bir Bürokrat ve Tarihçi İdris-i Bidlîsî, 458; Severcan, Kemalpaşazâde Tevarih, 78-84; Hoca Sadettin Efendi, Tacü't- Tevarih, 187.

${ }^{60}$ Celâlzâde Mustafa Çelebi, Selim-Name, 343-350.
} 
Misır seferinin tamamlanmasının ardından, bu toprakların sahibi olarak Yavuz Selim adına hutbeler okunmuştur. Müslümanlar için önem arz eden 3 şehri (Mekke, Medine, Kudüs) de elinde bulunduran Osmanlı Padişahları Hâdimü'l-Haremeyn yani Mekke ve Medine' nin hizmetkârı olarak anılmaya başlamıştır. Hutbelerin okunması ve bu hutbelerde Yavuz'un Hâdimü'l-Haremeyn olarak zikredilmesini hâlifelik olarak nitelendirenler bulunsada söz konusu unvan o dönemde siyasî yetkisi ve otoritesi olmayan hâlifeye değil Sultanlara verilen bir unvan olmuştur. ${ }^{61}$ Yavuz Selim bu toprakların hâkimi olarak hutbe okutmuştur. Ayrıca bir hilâfet vurgusu yapılmamıştır. ${ }^{62}$ Öte yandan Yavuz Selim' in Mısır'a girişini nakleden dönem kaynaklarında halifeden ya hiç söz edilmemekte ya da padişahın halifeye itibar etmediği nakledilmektedir. ${ }^{63}$ Uzunçarşılı' nın da mevcut hâlifenin maiyetiyle birlikte İstanbul'a gönderildiği, Kanuni döneminde tekrar Kahire'ye gönderildiği ve maaş bağlanarak ölene kadar unvanı kullanmasına izin verildiği şeklindeki anlatımı ${ }^{64}$ bize göre Yavuz Selim'in öncelikli ve nihai hedefinin mevcut hilafet kurumu olmadığ 1 fikrini vermektedir. Eğer söz konusu sefer mevcut kurumun elde edilmesine binaen yapılmış olsa idi söz konusu unvanın kullanımına hem kendisinin hem de halefinin izin vermemesi gerekirdi.

\section{Dönemin Yazılı Kaynak ve Belgelerinde Unvanların Kullanımı ve Hilafet Vurgusu}

Osmanlı padişahları, genel olarak kullandıkları Bey-Gazi, Padişah, Sultan, Han, Kayser, Şah gibi unvanların değişik siyasî gelenekleri yansıttığını ve farklı iddialar taşıdığını biliyorlard1 ${ }^{65}$ Hâkimiyet ve nüfuzlarının temeli olarak gördükleri gazâ ve cihatta öncülüğgu yansıtacak biçimde Gazi unvanını, hâkimi mutlak hükümdar imajını kuvvetlendirmek için şehinşah ve padişah gibi özgün Sâsanî İmparatorluğu unvanlarını tercih etmişlerdir. İran' in mutlak hâkimi ve Pers Krallığg'nın varisi olduklarını vurgulamak için Şah, şahsında tüm dünyanın himaye bulduğu evrensel hükümdar anlamında Padişah-ı Âlem Penah, Roma İmparatorluğu varisliğini ifade etmek için Kayser ve Rum gibi unvanlar kullanmışlardır. ${ }^{66}$ $\mathrm{Bu}$ unvanları yalnızca Müslüman halkların değil içinde farklı unsurları barındıran üniversal bir devletin liderliği düşüncesini yansıtacak şekilde bilinçli olarak kullanmışlardır. Bu bilinçli kullanımdaki amaç rakip devletlerin meşruiyet temelleri karşısında yeni bir ideoloji inşasına yöneliktir. Çizilen padişah portresine göre Acem, Rum ve Arap hükümdarları ancak sultanın kulları mertebesindedir. ${ }^{67}$ Döneme ait kaynaklarda bu düşünceyi destekler mahiyette doğunun ve batının tek hükümdarı olma isteğini ifade etmek için İskender, Doğu ve Batı'nın Sultanı gibi unvanlara yer verilmiştir.

Dönem eserlerini incelediğimizde Yavuz Selim için yukarıda nitelediğimiz unvanların yanında bazı farklı unvanlar da zikredilmektedir. Yavuz Selim'i ve diğer Osmanlı Padişahlarını kasıtlı olarak hâlife diye nitelendiren müelliflerin dışında pek çok müellif böyle bir vurguda bulunmamaktadır. Yavuz Sultan Selim ve Şah İsmâil arasında mücadelede Osmanlılar, Şiî propaganda altında ezilen Sünnî Müslümanlarca İslam

\footnotetext{
61 Turan, Hilafet, 207-208.

62 Matrakçı Nasuh, Târih-i Âl-i Osmân, 316.

63 Celâlzâde Mustafa Çelebi, Selim-Name, 200-210; Hoca Sadettin Efendi, Tacü't-Tevarih, 330-339.

64 Uzunçarşıll, Osmanlı Tarihi, 6/280; Turan, Hilafet, 203.

65 Turan, Hilafet, 224.

66 Turan, Hilafet, 228.

67 Genç, Acem'den Rum'a Bir Bürokrat ve Tarihçi İdris-i Bidlîŝิ, 416.
}

Journal of Analytic Divinity, https://dergipark.org.tr/tr/pub/jad Volume $4 / 2$ 
dünyasının koruyucusu olarak görülmeye başlamıştır. Dönem kroniklerinde hilafetten çok bu vurgu ön plana çıkmaktadır. Bu konu dönemin siyasî kaygıları göz önünde bulundurulduğunda hilâfet meselesinden daha öncelikli bir konu halini almaktadır. 68

İdris-i Bitlisî́nin kalem aldığı eseri ${ }^{9}$ ve o dönemde yazılmış mektuplarını incelediğimizde Şah İsmâil' in kendisinin yaşadığı coğrafya olan Memlük topraklarına hâkim olması ve burada Sünnî olarak birtakım problemler yaşaması Bitlisî́nin olayları değerlendirirken taraflı yaklaşmasına neden olmaktadır. Yavuz Selim'in bütün faaliyetlerini dinî gerekçelerle izah etmeye çalışan İdris-i Bitlisî, “...Allah'ın gölgesi olması vesilesiyle Cemiyet-i vahdet mazharıdır. Kuşkusuz ordu, Allah'ın gölgesi olan o sultanın gölgesi altında toplanmazsa, vahdet davasın Firavunî ulûhiyet ve rablik derecesine vardıran bir kimseyle [Şah İsmail] savaşılamaz..."70 diyerek bakış açısını ortaya koymuştur. Osmanlı Padişahının hâlifeliğine işaret ettiği düşünülen Zillu'llahi fi'l-Ard yani Allah'ın yeryüzündeki gölgesi unvanı yalnızca İslam geleneğinde kullanılagelen bir ifade biçimi olmayıp Bizans geleneği içinde imparatorlar sıklıkla dünyanın sahibi ve tanrının gölgesi olarak adlandırılmıştır. Bu nitelemeyi kullanma geleneği genel olarak o dönemlerde hükümdarlara kutsallık atfetme gayelerinden ileri gelmiştir.71 Özel olarak Yavuz Selim'in hilâfetine delil teşkil edemeyeceğini düşünmekteyiz. Öte yandan Safevîlerle savaşan orduyu da İslam ordusu ve Asâkîr-i Mansûre olarak nitelemektedir.72 Yavuz Selim'i Sünn̂̀ Müslümanlarn koruyucusu, din sultanı, ${ }^{73}$ hâlifelerin tahtına oturan padişah, haremin koruyucu, küfür ve İslam ülkelerini fetheden Sultan, Hilâfet şiarl şahlarn en büyüğ̈̈, hilâfet mekânlı ehl-i iman sultanlarının sultanı, yeryüzü Hüsrevlerinin Hüdavendigar'ı ve mücahitlerin meliklerin Şehinşah'ı olarak anmaktadır. ${ }^{74}$ Eserde hâlife kelimesini kullandığı yerleri incelediğimizde hâlife kelimesini dini liderlik dışında kelime kökenindeki anlamıyla da kullandığını görmekteyiz. "Şahların kalıcılığı evlat iledir. Selef halefinin adı ile yaşar"75 sözüyle hükümdarın ardından tahta geçen kimseyi kastetmiştir. Öte yandan Beyazıt için "tehlikeli hilâfet işinden elini çekti, Hilâfeti Ahmet'e bırakacaktı" ibarelerini kullanarak Saltanat işlerini ifade etmektedir. Ancak genel olarak Mısır seferi öncesinde dahi Yavuz'un ve önceki Osmanlı Padişahlarının halife olduğunu söylemekte, İstanbul ve Edirne'yi Darü'l- Hilafet ${ }^{76}$ olarak nitelemektedir. Tüm bu söylediklerimiz sonucunda onun Yavuzu Halife olarak gördüğü ya da öyle olmasını istediği kanaatine varmaktayız.

Dönemin önemli isimlerinden Kemâl Paşazâde'nin eserlerini77 incelediğimizde Mısır seferi ile ilgili kısımlara ulaşılamamış olması nedeniyle yorumda bulunamasak da genel

\footnotetext{
68 Turan, Hilafet, 207.

69 İdris-i Bidlîsî, Selim Şah-Nâme.

${ }^{70}$ Vural Genç, “İdris-i Bidlîsî’nin II. Bayezid ve I. Selim'e Mektupları”, Osmanlı Araştırmaları Dergisi 47 (2016), 171.

71 Turan, Hilafet, 226.

72 Genç, “İdris-i Bidlîsî́nin II. Bayezid ve I. Selim'e Mektupları”, 169.

73 İdrîs-i Bidlîsî, Selim Şah-Nâme, 285.

74 İdrîs-i Bidlîsî, Selim Şah-Nâme, 50-54; Genç, “İdris-i Bidlîsî’nin II. Bayezid ve I. Selim'e Mektupları”, 161.

75 İdrîs-i Bidlîsî, Selim Şah-Nâme, 50.

76 İdrîs-i Bidlîsî, Selim Şah-Nâme,103.

77 Kemâl Paşazâde, Kemâl Paşazâde Dîvânı, çev. Ahmet Cevdet (Dersaadet: İkdam Matbaası, 1896); Severcan, Kemalpaşazâde Tevarih,1.
} 
olarak İbn Kemal'in olaylara bakışı ve Yavuz hakkındaki nitelemeleri elimizde mevcuttur. İbn Kemal, Yavuz Selim tarafından Sünnî akideyi savunmak ve halkı Safevî tehlikesine karşı örgütlemekle görevlendirilmiştir. Üstlendiği misyonun da etkisiyle Kemâl Paşazâde olayları bu bakış açısıyla yorumlamış ve bu durumda anlatımına tesir etmiştir. $\mathrm{O}$, kendi dönemine kadar olan Osmanlı padişahlarını hâlife, Osmanlı saltanat makamına da hilâfet makamı olarak değerlendirmektedir. ${ }^{78}$ Ona göre Osmanlı padişahları, İslam'ın bilhassa Ehl$i$ Sünnet akidesinin koruyucusudurlar. Osmanlı sinırları Diyar-1 İslam sinırıdır. Bu padişahlara verilen lakap ve sıfatlar, diğerlerine verilmez. Padişahlara "Sâhib-kıran-ı âlem, Sultân-ı ulu'l-Âzâm, Kayser, Sultan-ı asr, Sultan-ı salâtînü'l-Arabî ve'l-Acemî ve't-Türkî ve'rRumî ve'd-Deylem, Cenâb-ı kamyâb. Hüdâvendigâr, Şehriyâr- 1 bahire, Fatih-i Şamat-ı Kâhire, Kahiru'l-mülûk-i şehriyar, Sultan-ı İslam, Hazret-i padişah- 1 cihan-penah, Sultan-ı cihan, Sahib kıran-ı zaman, manzur-ı subhan . . ."79 gibi unvanlar verilir. Kemâl Paşazâde ve İdris-i Bitlisî genel anlamda Osmanlı padişahlarının İslam adına hizmetlerini ve Yavuz Selim'in Şah ile Mücadelesi sırasındaki Ehli Sünnet Müslümanlarının koruyuculuğu rolünü hilâfetle ilişkilendirmektedirler.

Yavuz Selim'i Büyük İskender'e benzeten Şehsuvar Ali Bey ise Şükrü Bitlisî́den İskender Name gibi bir eser yazmasını ister. ${ }^{80} \mathrm{Bu}$ istek doğrultusunda hareket eden Şükrü Bitlisi'nin kaleme aldığı eserini ${ }^{1} 1$ incelediğimizde İskender gelenekli, doğu ve batı ülkelerinin fatihi bir Yavuz Selim portresi çizilmektedir. Eserde hem Osmanlıların fi-sebilillah gayesiyle İslam adına hizmetlerinin hem de söz konusu dönemde devam eden SafevîOsmanlı mücadelesinin etkisiyle Şah-ı din penah (İslam dininin koruyucusu Şah), İslam'ın Hevadarı (İslam'ın Aşığı, Taraftarı) olarak anılmıştır. ${ }^{82}$ Ancak Kemal Paşazade ve İdris-i Bitlisi'nin aksine Osmanoğlu'nun hizmetleri halifeliğe yorulmamış, Allah yolunda gazâ etme görevinin bir neticesi olarak görülmüsstür. Mısır seferi ve sonrasıyla ilgili anlatımlarda dahi Yavuz Selim'in hâlife olma isteğinden bahsedilmemiş ve hâlife vurgusu yapılmamış olup, İskender, Şah-ı Rum vasfıyla ön plana çıkmıştır. ${ }^{83}$

Lütfü Paşa, Yavuz Selim'in bütün seferlerinde yanında bulunan bir kimse olarak naklettiği bilgiler bizler için önem arz etmektedir. Ancak eserindeki ${ }^{84}$ genel fikir yapısına baktığımızda Selçuklu ve Osmanlı devletlerinin davranışlarını hatasız görüp diğer İslam devletlerinin mutlaka eksik ve yanlışları olduğunu düşünmekte, Yavuz selim ve diğer Osmanlı padişahlarını her yüzyılda Ehl-i Sünnet itikadını müdafaa ve ihya eden kimseler olarak nitelendirmektedir. Dinin koruyucusu ve yardımcısı olarak gördüğü Yavuz Selim' in "bize Zillu'llah ve Sultan- ehl-i İslam de lakab komuşlardır. Niçün ehl-i İslam mu 'ini ve Hevadar olmayuz..." dediğini aktarmaktadır. Genel olarak Yavuz'u, Padişah-ı 'âlem-guşa, İskender, el gazi u fi sebilillah, Hâdimü'l-Haremeyn (söz konusu unvanın o dönemde hâlifeye değil bizzat o bölgeye hâkim olan Sultana verildiğini söylemiştik.), malikü'l-berreyn ve'l-bahreyn ${ }^{85}$ olarak

\footnotetext{
78 Severcan, Kemalpaşazâde Tevarih, 94.

79 Uğur, İbn-i Kemâl, 36.

80 Şükrü Bitlisî, Selîm-nâme, 5.

81 Şükrü Bitlisî, Selîm-nâme.

82 Şükrü Bitlisî, Selîm-nâme, 308.

83 Şükrü Bitlisî, Selîm-nâme, 263-274-286.

84 Atik, Lütfü Paşa ve Tevârih-i Âli Osman.

85 Atik, Lütfü Paşa ve Tevârih-i Âli Osman, 73.
}

Journal of Analytic Divinity, https://dergipark.org.tr/tr/pub/jad Volume $4 / 2$ 
övmektedir. Mısır seferi ve sonrasındaki anlatımda da Yavuz Selim'i Şah-ı Cihan ve Sultan olarak nitelemekte ancak halifeliğine dair bir vurgu yapmamaktadır. ${ }^{86}$

Gelibolulu Mustafa Âli'nin eserindeki ${ }^{87}$ kullanım şekillerine baktığımızda Yavuz Selim'i Şah, İskender-i zamane, Sultan-ı zi-Zemin (Yeryüzüne sahip olan Sultan), Âlem-i Padişahiyan Şehriyari cihan (Cihan Hükümdarı) ${ }^{88}$ gibi sıfatlarla nitelemekte ve onun amacinın Âlem fethi olduğu zikredilmektedir. ${ }^{99}$ Şah İsmâil üzerine yapılan seferi anlatırken Yavuz Selim' in "Allah'ın dinine yardımo olun uyarnca ve saltanat namusunu korumak ve mazluma yardım eli uzatmak için bu seferi yapıyorum..." 90 dediğini nakletmektedir. Yavuz Selim'in hâlifeliğin ötesinde bütün Müslümanlara yönelik hitapla dini bir hassasiyetle hareket ettiğini ifade etmektedir. Mısır seferi ve sonrasıyla ilgili anlatımlar da halife vurgusu bulunmamakla birlikte Yavuz Mısır Şahı, Cihansitan (Cihanı fetheden), Yusuftahtının sahibi ${ }^{91}$ olarak anılmaktadır. Büyük bir Selim taraftarı olan Celâlzâde Mustafa'nın eserini ${ }^{92}$ incelediğimizde müellifin hâlifelikten ziyade Yavuz Selim'in üniversal liderliğine vurgu yaptığını görmekteyiz. ${ }^{93}$ Yavuz Selim'i Mısır seferi sonrasında dahi Şehenşah, Sultan, Sahibkıran, Padişah, Zem'in-ü-zaman, şahı Sultan-ı Rum unvanlarıyla zikretmektedir. ${ }^{94}$

Dindar bir kişi ve Yavuz taraftarı olan Keşfî́nin eserine ${ }^{95}$ baktığımızda tıpkı İdris-i Bitlisi gibi Yavuz Selim'in tüm faaliyetlerini dinî bir karakterde aktarmaktadır. Hilâfet kelimesini belirli yerlerde zikreden müellifimiz kelimeyi saltanatla eş anlamda kullanmıştır. ${ }^{96}$ Gerçek anlamda Mısır seferi ve sonrasında hilâfeti alan Sultan için kullanması gereken hâlife ifadesine Yavuz Selim'in kardeşleriyle olan mücadelesin de "hilafetine(hükümdarlığına) muhalif olanların işini bitirdi" diyerek yer vermiştir. Mısır seferi ve sonrasında ise Yavuz Selim için; "Mısır tahtına oturdu." "Pes her kişi Padişah-ı (İskender)Sikender-der ve şahen-şâh-ı Feridûn-fer să̆ olsun deyüp(diyip)..." "Pes şehriyâr-ı Suhrâb-heybet ve Rüstem-ceng ve kam-kar-ı Darâb-şevket-i Sikender-nâm-u-neng Hazretlerinin fermanıla..." "...Yine ol mahalde padişah-ı rû-yi zemin ve şahen-şah-i mülk-i din devletinde..."97ifadeleriyle nitelemektedir.

İshak b. İbrahim'in Selimname'sinde genel olarak Yavuz Selim Şehriyar, Hazret-i Hüdavendigar, şehriyar-1 sahipkıran şark ve garb, Sultan-1 Selâtin-i Cihan fahr-i Âl-i Osman, olarak nitelemekte ve Saltanata vurgu yapmaktadır. Hilâfete dair vurgunun yer almadığı eserde yalnızca din penah ifadesine gazâda yapılan öncülüğge nispeten yer

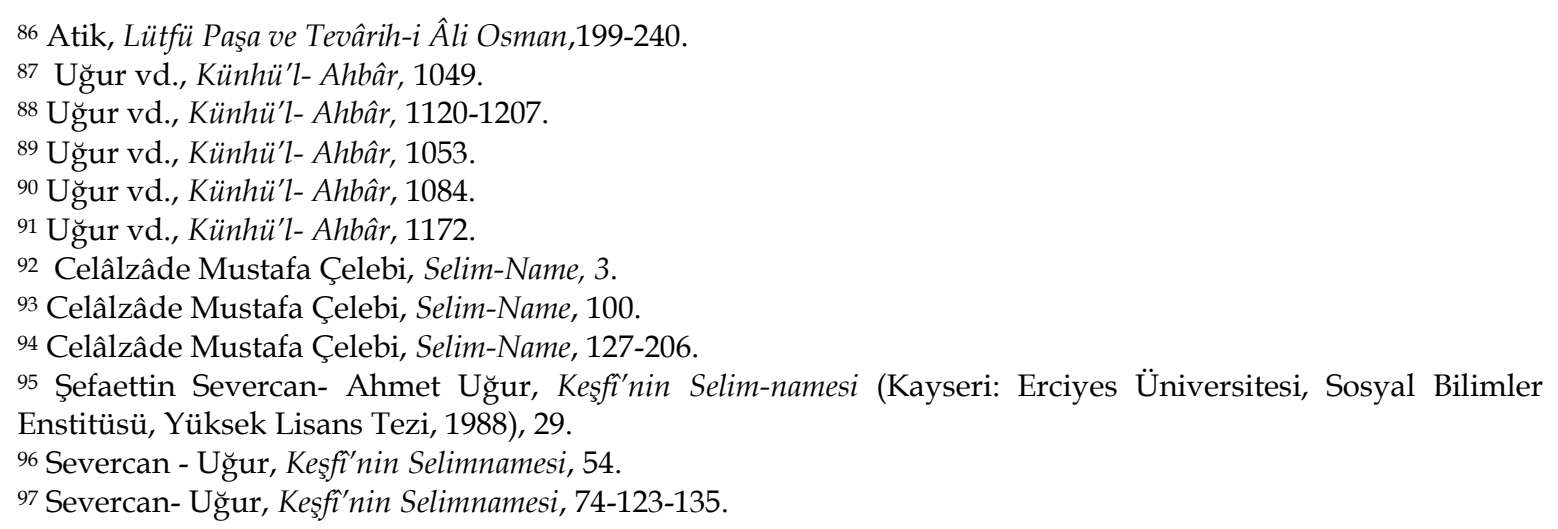


verilmiştir. ${ }^{98}$ Hadidî́ nin eserinde ${ }^{99}$ ise hilafete dair bir kullanım söz konusu değildir. Yavuz Sultan Selim'i Mısır seferi sonrasında bile ulu Şah, Süleyman-Saltanat, İskender-esfer, Cihan-dar, Feridun-fer olarak anmaktadır. ${ }^{100 Z e m b i l l i ~ A l i ~ E f e n d i ' n i n ~ O g ̆ l u ~ M u h i d d i n ~}$ Cemali'nin eseri101 o döneme kadar yazılmış Tarih kitaplarının bir derlemesi olup orijinal bir şey ortaya koymamıştır. Bu eserde de Mısır seferi sonrası Yavuz Selim için hâlife ibaresi kullanılmamıştır. ${ }^{102}$

Yavuz Selim dönemi şairlerinden Revânî́nin divanını incelediğimizde Yavuz Sultan Selim için" Kasîde der- Medh-i Sultân Selîm" isimli pek çok kasideye yer verdiğini görmekteyiz. Söz konusu dönemde meydana gelen olaylar üzerine yazılan kasideler de Yavuz Sultan Selim için pek çok övgü ifadesi ve unvan kullanılırken hâlife ve hilâfete dair bir kullanımla karşılaşılmamıştır. Şah İsmâil taraftarı olan Ahi'nin divanında ${ }^{103}$ gizli yakınma ifadeleri yer alsa da konuyla ilgili herhangi bir hitap bulunmamaktadır. Şiî düşünceye sahip bir yazarın Yavuz'u hâlife olarak övmesi beklenmemektedir. Ancak Şiî olmadığı ve Yavuz Selim'e nice övgüler de bulunan Revani gibi bir şairin hâlife olarak övmemesi dikkat çekicidir. ${ }^{104}$ Yavuz Selim' in ve Kanuni' nin divanlarını incelediğimizde de hâlifelik ve hilâfetle ilgili bir nitelemeyle karşılaşmadık. Yalnızca Yavuz Selim'in Taht ve Saltanat Allah'tandır vurgusu yaptığını görmekteyiz. ${ }^{105}$ Âşık Çelebi ve Zati'nin divanlarında hilâfetle ilgili bir ifadeye rastlanmamıştır. ${ }^{106}$

\section{Sonuç}

Yavuz Sultan Selim dönemi hilâfet telakkisini ele almaktaki amacımız hilâfetin Osmanlılara geçişine dair önemle altı çizilen 1517 yılının öncesi ve sonrasıyla dönem kroniklerine yansımasını, dönem insanının söz konusu meseleye bakışını ortaya koymaktı. $\mathrm{Bu}$ bağlamda yaşadıkları coğrafyanın temel dinamiklerini ve düşünce yapısını yansıtan müelliflerin farklı alanlarda kaleme aldıkları vesikaları inceleyerek hilâfet telakkilerini ve padişahı nitelemek için hangi unvanları kullandıklarını ifade etmeye çalıştık. Hilâfet konusunda yapılacak yorumların isabet etmesi için dönemin kendi dinamikleri içinde değerlendirilmesinin önem arz ettiğini düşünmekteyiz.

Bulunduğu coğrafyada söz sahibi olamayan bağımlı bir devletin istediği kitlelere hitap edebilmesi ve etkin bir mücadele sergileyebilmesi mümkün değildir. Yavuz Sultan Selim'de bize göre bu gerçekten hareket ederek devletinin içinde bulunduğu beka problemi (Şah İsmail ve taraftarları) karşısında bir savunma stratejisi geliştirmiştir. Öte yandan uluslararası ilişkilerde de sahip olduğu söz hakkı ve gücü korumak, cihan devleti ideali için güçlü bir irade ve otorite sergilemek istemiştir. Ancak döneme ait vesikalarda olayların

\footnotetext{
98 Burhan Keskin, Selîm-nâme İshâk b. İbrâhîm (İzmir: Ege Üniversitesi, Sosyal Bilimler Enstitüsü, Yüksek Lisans Tezi, 1988), 30-53.

99 Hadîdî, Tevârih-i Âli Osman, 5.

100 Hadîdî, Tevârih-i Âli Osman, 441-478.

101 Hasan Hüseyin Adalığlu, Muhyiddin Cemâlı̂'nin Tevârih-i Âlî Osmân'ı (İstanbul: Marmara Üniversitesi, Yüksek Lisans Tezi, 1990).

102 Adalıŏ̆lu, Muhyiddin Cemâlî’nin Tevârih-i Âlî Osmân'ı, 124.

103 Âhî, Divân, çev. Mustafa Kaçalın (Ankara: Kültür ve Turizm Bakanlığı Yayınları, 1994),10.

104 Revânî, Revânî Dîvânı, çev. Ziya Avşar (Ankara: Kültür ve Turizm Bakanlığı Yayınları, 2017), 64-145.

105 Yavuz Sultan Selim, Yavuz Sultan Selim Divanı, çev. Ali Nihad Tarlan (İstanbul: Ahmet Halit Kitabevi, 1946), 70.

106 İvaz Çelebi Zâtî, Divân (Toronto Üniversitesi Arşivi,); Es-seyyid Pir Mehmed bin Çelebi, Âsık Çelebi Dîvânı (Ankara: Kültür ve Turizm Bakanlığı Yayınları, 2017).
}

Journal of Analytic Divinity, https://dergipark.org.tr/tr/pub/jad Volume $4 / 2$ 
siyasî, sosyal ve ekonomik arka planı görmezden gelinerek yaşanan olaylar mezhebî ve dinî bir bakış açışıyla aktarılmaktadır. Söz konusu dönemin siyasî söylemleri genele yorularak tüm olaylar bu bağlam çerçevesinde değerlendirilmiştir. 1517 yılının öncesi ve sonrasında yaşanan olaylara bütüncül bir bakış açısıyla yaklaşıldığında Yavuz Sultan Selim'in seleflerinin aksine doğuya yönünü çevirmesinin dinî gerekçelerin yanı sıra siyasî, sosyal ve ekonomik sebepleri bulunduğunu ifade ettik. Buradan hareketle bu mücadelelerin yalnızca hilâfetle ilişkilendirilemeyeceğini düşünmekteyiz. Bu kanaatimizi ise; olmas1,

- Memlükler gölgesindeki hâlifenin itibar görmemesi ve etki alanının da sınırlı

- Yavuz Selim'in öncelikli hedefinin Asya'da kurulacak bir hakimiyetle stratejik öneme sahip ticaret yollarını kontrol etmek istemesi, Mısır seferi sonrasında dahi bu amaca yönelik politikalar izlemesi,

- Unvan kullanımları başlığı altında ayrıntılı olarak zikrettiğimiz müelliflerin az bir kısmı kasıtlı olarak Yavuz Selim'i ve diğer Osmanlı Padişahlarını hâlife diye nitelendirirken diğer müelliflerin böyle bir vurgu yapmaması,

- Misır seferi ardından dönem fetihnamelerinde ve bizzat sefere katılan müelliflerin kaleme aldıkları eserlerde Yavuz Selim, hilâfet ile ilgili bir beklentisinin dile getirilmemesi, Ayrıca Yavuz Selim adına Mısırın hâkimi olarak hutbe okunması ve hâlifelik namına ayrı bir vurgunun yapılmaması desteklemektedir.

Yavuz Sultan Selim'i hâlife olarak zikretmeyen müelliflerin cihan hakimiyeti mefkuresine uygun düşen Alem fatihliği vurgusu, dönem insanının algısını daha fazla yansıtmaktadır. Osmanlı Sultanlarının gazâ ve cihattaki önderlikle İslam âleminde edindikleri saygınlık göz ardı edilerek bu saygınlık ve önderliğin Mısır seferi ve sonrasında elde edildiğini düşünmek bize göre yanlış olacaktır. Elbette ki Hâdimü'l-Haremeyn unvanı Osmanlılara prestij sağlamıştır ancak söz konusu üstünlüğün yalnızca bu sefer ile elde edilen bir kazanım olmadığı aşikardır.

\section{Kaynakça}

Adalığlu, Hasan Hüseyin. Muhyiddin Cemâlı̂'nin Tevârih-i Âlî Osmân'ı. İstanbul: Marmara Üniversitesi, Sosyal Bilimler Enstitüsü, Yüksek Lisans Tezi, 1990.

Ağır, Abdullah Mesut. "Memlûk Sultanlarının Gölgesi Altında Hilâfet Kurumu”. Gaziantep Üniversitesi Sosyal Bilimler Dergisi 10/2 (2011), 638-645.

Âhî. Divân. çev. Mustafa Kaçalın. Ankara: Kültür ve Turizm Bakanlığı Yayınları, 1994.

Alkan, Mustafa. Osmanlılarda Hilafet. İzmir: Çağlayan Yayınları, 2. Basım, 1997.

Atik, Kayhan. Lütfü Paşa ve Tevârih-i Âli Osman. Ankara: Kültür BakanlığıYayınları, 1. Basim, 2001.

Azamat, Nihat. Anonim Tevarih-i Ali Osman. İstanbul: Marmara Üniversitesi Yayınları, 1992. 
Bidlîsî, İdrîs-i. Selim Şah-Nâme. çev. Hicabi Kırlangıç. Ankara: Kültür BakanlığıYayınları, 1. Basım, 2001.

Bitlisî, Şükrî-i. Selîm-nâme. çev. Mustafa Argunşah. Kayseri: Erciyes Üniversitesi Yayınları, 1. Basım, 1997.

Buzpınar, Ş. Tufan. "Osmanlı Hilafeti Meselesi: Bir Literatür Değerlendirmesi”. Türkiye Araştırmaları Literatür Dergisi 2/1 (2004), 113-131.

Celâlzâde Mustafa Çelebi. Selim-Name. çev. Ahmet Ahmet Uğur - Mustafa Çuhadar. Ankara: Kültür Bakanlığı Yayınları, 1990.

Çelebi, Zâtî, İvaz. Divân. Toronto Üniversitesi Arşivi, https:// search.library.utoronto.ca/search?Ns=Author\&N=20509\%20206305\%20429 $4966884 \&$ Nso=1\&uuid=93d294cc-65d0-4f10-95f7-a9f5221fe037.

Emecen, Feridun. "Selim I". Türkiye Diyanet Vakfi İslâm Ansiklopedisi. Erişim 12 Ocak 2020. https:// islamansiklopedisi.org.tr/selim-i

Erdoğan, Arif. Yavuz Sultan Selim'in Faaliyetlerinde Din ve Siyaset Faktörü. Ankara: Ankara Üniversitesi, Sosyal Bilimler Enstitüsü, Yüksek Lisans Tezi, 1998.

Es-seyyid Pir Mehmed bin Çelebi. Âsık Çelebi Dîvânı. çev. Filiz Kılıç. Ankara: Kültür ve Turizm Bakanlığı Yayınları, 2017.

Feridun Ahmet Bey. Münşeâtü's- Selâtîn. Ankara: TBMM Kütüphanesi, 71-5305.

Uğur, Ahmet vd. Gelibolulu Mustafa Âli Efendi Kitâbüt- Târih-i Künhü'l- Ahbâr. Kayseri: Erciyes Üniversitesi Yayınları, 1997.

Genç, Vural. Acem'den Rum'a Bir Bürokrat ve Tarihçi İdris-i Bidlîsî. Ankara: Türk Tarih Kurumu Yayınları, 1. Basım, 2019.

Genç, Vural. “İdris-i Bidlîsî'nin II. Bayezid ve I. Selim'e Mektupları”. Osmanh Araştırmaları Dergisi 47 (2016), 147-208.

Hadîdî. Tevârih-i Âli Osman. çev. Necdet Öztürk. İstanbul: Marmara Üniversitesi Yayınları, 1991.

Hakyemez, Cemil. Osmanlı-İran İlişkileri ve Sünni-Şii İttifakı. İstanbul: Kitap Yayınevi, 1. Basım, 2014.

Hakyemez, Cemil. "İbn Haldun ve İmamet- Siyaset Algısında Farklılaşma arayışları" Uluslararası İbn Haldun Sempozyumu. ed. Mesut Okumuş. Çorum: Çorum Belediyesi Kültür Yayınları, 2013.

Hoca Sadettin Efendi. Tacü't- Tevarih. çev. İsmail Parmaksızoğlu 4 Cilt. İstanbul: Devlet Kitapları Müdürlüğü-Milli Eğitim Bakanlığı Yayınları, 1. Basım, 1979.

İnalcık, Halil - Quataert, Donald. Osmanlı İmparatorluğu'nun Ekonomik ve Sosyal Tarihi. çev. Halil Berktay. İstanbul: Eren Yayıncılık, 2000.

Keskin, Burhan. İshâk b. İbrâhîm. Selîm-nâme. İzmir: Ege Üniversitesi, Sosyal Bilimler Enstitüsü, Yüksek Lisans Tezi, 1988. 
Karagöz, İsmail. Dini Kavramlar Sözlüğü. ed. İsmail Karagöz. Ankara: Diyanet İşleri Başkanlığı Yayınları, 5. Basım, 2010.

Kemâl Paşazâde. Kemâl Paşazâde Dîvânı. çev. Ahmet Cevdet. Dersaadet: İkdam Matbaası, 1896.

Severcan, Şefaettin. Kemalpaşazâde Tevarih-i Al-i Osman 10. Defter. Kayseri: Erciyes Üniversitesi, Sosyal Bilimler Enstitüsü, Doktora Tezi, 1991.

Matrakçı Nasuh. Rüstem Paşa Tarihi Olarak Bilinen Târih-i Âl-i Osmân. ed. Erhan Afyoncu. çev. Göker İnan. İstanbul: Türkiye Yazma Eserler Kurumu Başkanlığı Yayınları, 1. Basim, 2019.

Öngören, Reşat. "Safiyüddîn-i Erdebîlî". Türkiye Diyanet Vakfi İslam Ansiklopedisi Erişim 23 Ocak 2020. https:/ / islamansiklopedisi.org.tr/erdebili-safiyyuddin

Pakalın, Mehmet Zeki. Osmanlı Tarih Deyimleri ve Terimleri Sözlüğü.İstanbul: Milli Eğitim Basımevi, 2. Basım, 1971.

Pul, Ayşe. "Yavuz Sultan Selim'in Güney Siyasetinin Doğu Akdeniz Ticaretine Etkisi Hakkında Bazı Düşünceler". Selçuk Üniversitesi Türkiyat Araştırmaları Dergisi 35 (Haziran 2016), 263-289.

Revânî. Revânî Dîvânı. çev. Ziya Avşar. Ankara: Kültür ve Turizm Bakanlığı Yayınları, 2017. Severcan, Şefaettin - Uğur, Ahmet. Keşfínin Selim-namesi. Kayseri: Erciyes Üniversitesi, Sosyal Bilimler Enstitüsü Yüksek Lisans Tezi, 1988.

Sümer, Faruk. "Yavuz Selim Hilafeti Devraldı mı?" Belleten Dergisi 56/217 (Aralık 1992), 675-701.

Şimşirgil, Ahmet. KAYI III Osmanlı Tarihi- Haremeyn Hizmetinde. İstanbul: Timaş Yayınları, 9. Basim, 2013.

Turan, Namık Sinan. Hilafet: Erken İslam Tarihinden Osmanlı'nın Son Yüzyılına. İstanbul: İstanbul Bilgi Üniversitesi Yayınları, 1. Basım, 2017.

Uğur, Ahmet. İbn-i Kemâl. İzmir: Kültür ve Turizm Bakanlığı Yayınları, 1. Basım,1987.

Ulutaş, Adnan. Osmanl Imparatorluğu'nda Hilafet ve Saltanat Müesseselerinin Hukuki Mahiyeti. İstanbul: İstanbul Üniversitesi, Sosyal Bilimler Enstitüsü, Yüksek Lisans Tezi, 2007.

Uzunçarşıll, İsmail Hakkı. Osmanlı Tarihi. 2 Cilt. Ankara: Türk Tarih Kurumu Yayınları, 1988.

Üçer, Cenksu. Tokat Yöresinde Geleneksel Alevîlik. Ankara: Ankara Okulu, 3. Basım, 2015.

Yavuz Sultan Selim. Yavuz Sultan Selim Divanı. çev. Ali Nihad Tarlan. İstanbul: Ahmet Halit Kitabevi, 1946.

Yazıcı, Nesimi. İlk Türk-İslam Devletleri Tarihi. Ankara: Türkiye Diyanet Vakfı Yayınları, 13. Basım, 2016. 